\title{
Marine invasion genetics: from spatio-temporal patterns to evolutionary
}

\section{outcomes}

Marc Rius ${ }^{1, *}$, Xavier Turon ${ }^{2}$, Giacomo Bernardi ${ }^{3}$, Filip A.M. Volckaert ${ }^{4}$, Frédérique Viard $^{5,6}$

1 Ocean and Earth Science, University of Southampton, National Oceanography Centre, European Way, Southampton, SO14 3ZH, United Kingdom

${ }^{2}$ Centre for Advanced Studies of Blanes (CEAB-CSIC), Accés Cala S Francesc 14, E17300 Blanes (Girona), Spain

${ }^{3}$ Department of Ecology and Evolutionary Biology, University of California Santa Cruz. 100 Shaffer Road, Santa Cruz, 95060, CA, United States of America

${ }^{4}$ Laboratory of Biodiversity and Evolutionary Genomics, Department of Biology, University of Leuven, Charles Deberiotstraat 32 - box 2439, B-3000 Leuven, Belgium

${ }^{5}$ Sorbonne Universités, UPMC University Paris 06, Team Diversity and Connectivity in Coastal Marine Landscapes, UMR 7144, Station Biologique de Roscoff, F-29680 Roscoff, France

${ }^{6}$ CNRS, Laboratory Adaptation and Diversity in the Marine Environment, UMR 7144, Station Biologique de Roscoff, F-29680 Roscoff, France

* Correspondence author. E-mail: M.Rius@soton.ac.uk 


\begin{abstract}
Over the last 15 years studies on invasion genetics have provided important insights to unravel cryptic diversity, track the origin of colonizers and reveal pathways of introductions. Despite all these advances, to date little is known about how evolutionary processes influence the observed genetic patterns in marine biological invasions. Here, we firstly review the literature on invasion genetics that include samples from European seas. These seas constitute a wide array of unique water masses with diverse degrees of connectivity, and have a long history of species introductions. We found that only a small fraction of the recorded introduced species has been genetically analysed. Furthermore, most studies restrict their approach to describe patterns of cryptic diversity and genetic structure, with the underlying mechanisms involved in the invasion process being largely understudied. Secondly, we analyse how genetic, reproductive and anthropogenic traits shape genetic patterns of marine introduced species. We found that most studies reveal similar genetic diversity values in both native and introduced ranges, report evidence of multiple introductions, and show that genetic patterns in the introduced range are not explained by taxonomic group or reproductive strategy. Finally, we discuss the evolutionary implications derived from genetic patterns observed in non-indigenous species. We identify different scenarios that are determined by propagule pressure, phenotypic plasticity and pre-adaptation, and the effects of selection and genetic admixture. We conclude that there is a need for further investigations of evolutionary mechanisms that affect individual fitness and adaptation to rapid environmental change.
\end{abstract}

Keywords: Europe, hybridisation, introduced species, invasion routes, cryptic invasion, population genetics 


\section{Introduction}

Evolutionary genetics is a well-established and fertile field of research that has been central for understanding biological invasions (Lee 2002). It has provided the opportunity to unravel concealed patterns and processes involved with species introductions (e.g. Balanyà et al. 1994; Taylor and Keller 2007; Cadotte et al. 2009; Lawson Handley et al. 2011) and has boosted contentious scientific debates (e.g. genetic paradox in invasion biology, Tsutsui et al. 2000; Frankham 2005; Roman and Darling 2007). Population genetics, molecular barcoding and phylogenetics are increasingly being used to understand aspects of biological invasions such as cryptic diversity and cryptic introductions, tracking the origin of introductions or characterising colonisation pathways (Estoup and Guillemaud 2010; Geller et al. 2010). The term 'invasion genetics' was coined in the late 1990s (Villablanca et al. 1998; Davies et al. 1999) and since then invasion genetics studies have proliferated, fuelled by both methodological and analytical advances in genetic techniques (Cock et al. 2010; Reitzel et al. 2013).

As is the case in the field of ecology (Menge et al. 2009), terrestrial and aquatic invasion biology studies have historically progressed in relative isolation (Ruiz et al. 2000; Kolar and Lodge 2001; Grosholz 2002; Callaway and Maron 2006). This may be due to the traditional design of academic pathways or the idiosyncratic and/or antagonistic characteristics of these ecosystems. However, there is no reason to maintain this segregation, as most concepts in invasion biology are applicable across ecosystems (e.g. Roman and Darling 2007; Wilson et al. 2009; Blackburn et al. 2011). Marine ecosystems have a broad range of characteristics that make them ideal model systems for invasion genetics studies. This includes the open nature of the seascape, the diversity of life-histories and dispersal capabilities of marine biota, and the type and frequency of introduction vectors (see details below). Holland (2000) produced the first study that specifically reviewed knowledge on 
marine invasion genetics and detailed the usefulness of genetic techniques for understanding ecological processes involved in biological invasions. More recently, a study reviewing the latest findings in marine invasion genetics emphasized the practicality of genetic tools for the identification of cryptic invasions and sources of introduced populations (Geller et al. 2010). However, to date no review has addressed the link between observed genetic patterns and evolutionary processes in marine biological invasions.

In this review, we begin by examining all available information from invasion genetic studies conducted using samples collected from European seas to assess the state of knowledge and the importance of a number of genetic and life-history traits relevant for colonisation and spread. We chose the marine waters surrounding Europe (NE Atlantic Ocean and the Baltic, Mediterranean and Black seas) as this region provides an excellent setting to investigate genetic patterns related to marine biological invasions. European shores comprise a wide array of unique water masses with diverse degrees of connectivity. Also, they have a long history of species introductions - both as a donor and as a receiver (e.g. Patti and Gambi 2001; Roman and Palumbi 2004; Rius et al. 2014). We then analyse how genetic diversity, reproductive strategies and anthropogenic vectors shape invasion genetic patterns. From there we obtain and discuss insights into the evolutionary processes that may underlie biological invasions and how the latest developments in genetic techniques can help to unravel these.

\section{History, regional specificities and genetic patterns of European seas}

Inhabitants of the European region were amongst the first sailors to establish transoceanic routes for commercial and colonisation purposes (Scammell 1981). This represented the dawn of long-distance artificial translocation of marine species. European shipping traffic to African, American and Asian shores commenced in the $15^{\text {th }}$ century (Scammell 1991), which established global commercial routes. Europe has been the cradle of taxonomy, and as a result descriptions of marine species from both Europe and abroad 
emerged in the eighteenth / nineteenth centuries, when transoceanic shipping had already been in place for centuries. Many species that arrived in Europe in historical times were mislabelled as native simply because they were already there when taxonomists came on to the stage (Carlton 2000; Carlton 2009). Many purportedly 'European' species are simply early introductions, or should be labelled at best as cryptogenic species (Carlton 1996; Haydar 2012). Consequently, Europe is plagued with historical taxonomic problems and instances of 'pseudoindigenous' species (sensu Carlton 2009). Genetic tools have greatly helped to resolve this issue (Geller et al. 2010), although in some cases the genetic signal has been blurred by centuries of global transportation. Thus, it is nowadays extremely challenging to track the origins and introduction pathways of cosmopolitan species or species complexes (e.g. Zhan et al. 2010; Pineda et al. 2011; Pérez-Portela et al. 2013).

Concerning the geographic particularities of the European region, the NE Atlantic Ocean shores include some of the most frequented shipping harbours worldwide (Kaluza et al. 2010; Keller et al. 2011). These harbours have provided an extensive and long-term manmade interchange of marine biota among temperate regions, and such exposure to introductions has led to high propagule pressure within the N Atlantic region (Briski et al. 2012). Such large contingents of introduced individuals have resulted in a long list of reported non-indigenous species, often complemented with accurate species range descriptions, but rarely studied in detail retrospectively (how did the introduction and expansion happen?) or prospectively (what are the chances for future introductions?) (but see for example Bolte et al. 2013). Another peculiarity of the European seas is the presence of important semi-enclosed seas, namely the Baltic, Mediterranean and Black seas. These basins are connected to 'outside basins' by extremely narrow links (Kattegat / Skagerrak, Gibraltar, and Sea of Marmara). This particular geographic setting has led some authors to consider these seas as giant mesocosms, 
whereby the outcomes of 'natural experiments' occurring there have the potential to enhance our understanding of major processes affecting the world's oceans (Lejeusne et al. 2010).

The Mediterranean Sea is the most altered and invaded of all European seas, with recent estimates of the number of introduced species ranging between 500 to 1000 species (Streftaris et al. 2005; Streftaris and Zenetos 2006; Galil 2009; Coll et al. 2010; Zenetos et al. 2012). The Gibraltar strait represents a strong biogeographic break (Patarnello et al. 2007) and is a hub of human activity, making it difficult to disentangle natural range expansions from human-related species introductions (Rius et al. 2012; Zenetos et al. 2012). The opening of the Suez Canal in 1869 initiated a species migration from the Red Sea to the Mediterranean Sea (the so-called Lessepsian migration) (Streftaris et al. 2005; Galil 2009; Coll et al. 2010). To date more than 330 alien species are considered to have been introduced through the Suez Canal, resulting in a drastic biodiversity change in the Mediterranean Sea (Galil 2007; Galil 2012; Belmaker et al. 2013). However, the perception of the role of the Suez Canal and the Gibraltar Strait as entrance gates may be biased by the failure to recognize early introductions as such (as outlined above), while modern introductions are more easily identifiable. The Lessepsian invasions represent a unique scientific model, as the date of the opening of the Canal is known and the route of invasion is generally unidirectional. Thus, the Lessepsian system allows, within a relatively simple setting, for the testing of specific hypotheses related to the genetics of biological invasions. For example, Lessepsian introductions support the idea that reduction in genetic diversity is not inherent to the invasion process, because since the earliest genetic studies of Lessepsian species, little evidence for genetic bottlenecks has been found (Golani and Ritte 1999; Hassan et al. 2003; Hassan and Bonhomme 2005; Azzurro et al. 2006; Bernardi et al. 2010). In only one instance, namely that of the highly successful introduced bluespotted cornetfish Fistularia commersonii, is there evidence of lowered genetic diversity in the Mediterranean Sea (Golani et al. 2007; Sanna et al. 2011). 
Contrary to what happens with the Lessepsian connection, the Black Sea and adjacent Azov Sea are naturally connected to the Mediterranean Sea, albeit with extreme restrictions at the Bosphorus and Dardanelles, which are very shallow straits (approximately $50 \mathrm{~m}$ in depth) (Yaltırak et al. 2000). Additionally, the influx of freshwater into the Black Sea results in lower salinity compared to the Mediterranean Sea (Sorokin 2002). This translates into the Black Sea waters naturally flowing out towards the Mediterranean, through an upper layer of lower salinity water, while higher salinity Mediterranean water tends to flow in towards the Black Sea as a bottom layer, (similarly to the situation in the Gibraltar strait, where the heavier Mediterranean water flows out towards the Atlantic Ocean) (Murray et al. 1991; Sorokin 2002). Due to these particularities, the Mediterranean and Black seas' biota have been isolated with strong limitations to gene flow in place. However, in recent years, changes in the hydrology and abiotic characteristics of the Black sea, together with an increase in ship traffic, have made this natural boundary more permeable (Gregg and Özsoy 2002). Contrary to the Lessepsian situation, the source and route of biological introductions to and from the Black Sea need to be studied carefully, as they may follow different modes. For example, the ctenophore Mnemiopsis leidyi, which displays a native range along the eastern seaboard of the United States of America (Reusch et al. 2010), was first recorded in the Black Sea and only later recorded in the Mediterranean Sea (Ghabooli et al. 2011). Genetic studies, based on mitochondrial and nuclear markers confirmed that this ctenophore species was first introduced in the Black Sea (supposedly via ballast water from the Gulf of Mexico Reusch et al. 2010), and from there invaded the Mediterranean Sea (Ghabooli et al. 2013). These results are consistent with a similar study based on microsatellite markers (Bolte et al. 2013) and, importantly, with the overall hydrography of the region, where surface water (where dispersive propagules are more concentrated) tends to flow out of the Black Sea into the Mediterranean Sea. 
Finally, the Baltic Sea includes coastal ecosystems with brackish waters that are considered important centres of xenodiversity (Leppa $\square$ koski et al. 2002). The oceanographic similarity between the Black and Baltic seas has led to large scale colonisation pressure of Ponto-Caspian taxa of which representatives of crustaceans (e.g. Cristescu et al. 2004; Cristescu and Hebert 2005; Audzijonyte et al. 2007; Audzijonyte et al. 2013) and gobiids (e.g. Brown and Stepien 2008; Feldheim et al. 2009; Neilson and Stepien 2011) have been traced genetically. In some cases, such as with the introduction of the polychaete species Marenzelleria neglecta, M. viridis and M. arctia (Blank and Bastrop 2009), the introduction of non-indigenous species has resulted in significant biogeochemical impacts on coastal ecosystems of the Baltic Sea (Norkko et al. 2012).

\section{Literature review}

Table S1 lists 87 studies on invasion genetics (as of 2013, the last full year available) that include samples from European seas, including information on taxonomic affiliations, natural dispersal capabilities, genetic markers used and some major genetic traits. Genetic studies of alien species in European seas started in the 1990s with allozyme analyses, and were subsequently followed by studies using DNA sequence and microsatellite data. Mitochondrial DNA, particularly the cytochrome c oxidase subunit I gene, remains the most widely used genetic marker (44\% of the studies). One surprising result from this review is that after an initial period (1996-2003) of low publication rate (average of 2.3 works per year), the rate increased in 2004 but has since remained fairly constant (average of 7.1 works per year during the period 2004-2013) (Fig. 1A). This is despite a boom in the use of genetic tools in marine research in recent years (e.g. Uriz and Turon 2012).

The geographic areas covered by these studies are depicted in Fig. 1B, showing a predominance of studies covering the NE Atlantic Ocean and the Mediterranean Sea, while smaller areas such as the Baltic and Black seas were the subjects of fewer studies. When we 
analysed the taxonomic affiliation of studied taxa (Fig. 1C), we found a clear dominance of chordates. Taking as a reference point the taxonomic distribution of alien species reported by Zenetos et al. (2012) in the Mediterranean Sea, the major introduced groups are Mollusca, Crustacea, Polychaeta, Macrophyta, and Fish. Of these, only Macrophyta and Fish have received attention to match their importance in terms of genetic studies (Fig. 1C). In turn, ctenophores, and particularly ascidians, are overrepresented in genetic studies.

The results strongly favour the notion that genetic diversity is not generally impaired when species are introduced. Of the ca. $54 \%$ of studies that did compare genetic diversity in both native and introduced populations, the majority of them (ca. 74\%) found similar diversity in some or all introduced populations. Only ca. $23 \%$ of the studies reported lower genetic diversity in introduced populations, with one study (ca. $2 \%$ ) reporting higher diversity in the introduced range (Fig. 1D). Interestingly, when we categorized the dispersal capabilities of the species from studies that compare genetic diversity between native and introduced populations into short dispersal (pelagic lifetime less than one week, usually corresponding to lecitotrophic larvae or direct developers) and long dispersal (pelagic lifetime more than one week, corresponding to long-lived propagules or planktotrophic larvae), we found that both strategies are represented (Fig. 1D). However, we found a slightly higher frequency of forms with long dispersal abilities in species with similar genetic diversity in native and introduced populations (ca. $63 \%$ vs ca. $55 \%$ of species featuring higher diversity in the native populations). Almost half of the studies in Table S1 (ca. 47\%) reported evidence of multiple introductions. This percentage reaches ca. $57 \%$ in studies reporting similar diversity in native and introduced populations, but drops to ca. $45 \%$ in studies that found higher diversity in native populations. Overall, the evidence from published studies points towards a low frequency of founder effects (i.e. severe genetic drift responsible for a loss of genetic variation after the colonisation of a new site by a limited number of individuals) in marine 
introductions to European waters, with multiple introductions playing an important role in generating genetic patterns.

As a whole, we found a dearth of genetic studies of European introduced species. Out of an estimated 500 - 1000 introduced species (Zenetos et al. 2012), the reviewed genetic studies focussed on only 59 species (or species-complexes). In addition, most studies reviewed here have focussed on resolving cryptic diversity and describing patterns of genetic structure across species ranges, with little work done on adaptive or evolutionary processes.

\section{Genetic diversity, reproductive strategies and anthropogenic vectors}

Marine genetic studies routinely encounter a realm full of cryptic diversity (Appeltans et al. 2012). This requires uncovering and understanding a wealth of ecological and evolutionary mechanisms ruling speciation. Studies on marine biological invasions face an additional challenge as a result of human transport, which can determine the distribution of genotypes of species or species complexes (e.g. Daguin and Borsa 2000; Pérez-Portela et al. 2013; Rius and Teske 2013). Even within well-defined genetic lineages, the relationship between genetic diversity and colonisation success has generated an intense debate in the invasion biology literature. Genetic studies consistently show that marine biological invasions are often characterized by the presence of high propagule pressure from multiple and highly divergent sources from the native range (e.g. Simon-Bouhet et al. 2006; Rius et al. 2012). Another possibility is that the high genetic diversity of localized introduced populations is explained by introductions from a few but genetically highly polymorphic sources (Riquet et al. 2013), a feature that has also been documented in terrestrial populations (Meimberg et al. 2010). Based on these two processes (i.e. introduction from genetically disparate sources or genetically diversified sources), the introduced range generally has similar or higher mean values of genetic diversity than the native range (e.g. Crepidula fornicata, Fig. 2). However, there are exceptions to this (Koskinen et al. 2002; Gaither et al. 2012) and important 
population processes such as genetic bottleneck, genetic drift, lag period and / or Allee effects (Tsutsui et al. 2000; Leung et al. 2004; Crooks 2005; Dawson \& Hamner 2005; Taylor and Hastings 2005) can be responsible for reducing levels of genetic diversity. Some studies on marine introduced species have indeed reported low levels of genetic diversity (e.g. Provan et al. 2005; Dupont et al. 2007b; Golani et al. 2007; Tepolt et al. 2009; Pérez-Portela et al. 2012; Rius and Shenkar 2012). In some species, strong founder effects during expansion may result in a decrease in genetic diversity over time (e.g. Perophora japonica, Pérez-Portela et al. 2012) or create an expansion wave (see Ciosi et al. 2011 for a terrestrial example). It has been shown that such low levels of genetic diversity do not generally compromise population establishment and the spread of non-indigenous species (Roman and Darling 2007). Some studies report a complex interplay of primary and secondary introductions (also called preborder and post-border stages, see Forrest et al. 2009), with the former transfer happening unidirectionally (from the native to the introduced range), while the latter occurs within the introduced range. In such cases, the native range is normally characterized by a well-defined genetic structure while the introduced range is diverse but highly homogenous (Voisin et al. 2005; Simon-Bouhet et al. 2006; Rius et al. 2012). When human-mediated transport results in bi-directional relocation of propagules between the native and introduced ranges, a random reshuffling of genotypes occurs, which may lead to global genetic homogenisation (Zhan et al. 2010; Pineda et al. 2011).

When genetic attributes are compared among species with different reproductive strategies, common outcomes can been found. For instance, both poor dispersers, such as direct-developers (e.g. the gastropod Cylope neritea, Simon-Bouhet et al. 2006) or species with lecitotrophic larvae (e.g. the ascidian Microcosmus squamiger, Ordóñez et al. 2013), and highly dispersive species, like bentho-pelagic species with long-lived larvae (e.g. the gastropod Crepidula fornicata, Riquet et al. 2013 and references therein), are all successful 
invaders that show no reduction in genetic diversity compared to the native range. This is counterintuitive as in the absence of human-mediated transport of species, short and long planktonic larval duration display different dispersal kernel distributions and thus dissimilar genetic dispersal estimates (Siegel et al. 2003). Differences may be expected when considering social organisation or gregarious behaviour. For instance, colonial vs. solitary ascidians were shown to display contrasted genetic patterns in their native range (Ayre et al. 2009). And yet, both colonial and solitary non-indigenous species show similar genetic patterns (Bock et al. 2011; Goldstien et al. 2011; Bock et al. 2012; Rius et al. 2014). Taken together, genetic studies analysing the role of reproductive strategies of introduced species suggest that these different strategies have little effect on the composition and distribution of genetic signatures.

The open nature of most seascapes prevents the efficient containment of introduced marine species and facilitates the spread of initial and successive waves of founders in the wild. Such spread has been demonstrated using bio-physical modelling of the larval dispersal of the $C$. fornicata in its European introduced range (Viard et al. 2006; Dupont et al. 2007a). Furthermore, the long-lived larval stages of many marine organisms allow them to typically remain in the water column for a few weeks (Shanks 2009), which might be an advantageous trait in artificial transportation (e.g. ballast waters). In addition, organisms can survive long periods of transport time (e.g. several months for the benthic amphipod, Corophium acherusicum, in ballast water tanks, Gollasch 1996). In yet another instance, Gollasch et al. (2000) showed that the abundance of the copepod Tisbe graciloides grows exponentially in ballast waters irrespective of transport time and species diversity. Anthropogenic vectors (e.g. ballast waters, aquaculture, and fouling of ship hulls and sea-chests) represent highly efficient ways to transport large numbers of individuals per species and an array of species (Carlton and Geller 1993; Cohen and Carlton 1998; Carlton 2001). Similarly, marine infrastructures 
(i.e. man-made mobile or immobile structures) have been identified as major vectors for both primary introductions and subsequent expansions (i.e. stepping stones, corridors or bridgehead effects; Bulleri and Airoldi 2005; Dafforn et al. 2009; Mineur et al. 2012). However, studies comparing different vectors are needed. For example, ballast water is known to be very effective at transporting invertebrate larvae but most likely plays a minor role in the transport of fish species (with the notable exception of the round goby, Neogobius melanostomus, introduced from the Black Sea to the Great Lakes, Fuller et al. 2014). Ship fouling is a non-selective vector for non-indigenous benthic species, particularly those that take refuge in sea chests and other structures less exposed to drag during navigation (Coutts and Dodgshun 2007). In another notable instance, recreational boating is an important vector for the spread of non-indigenous species (Acosta and Forrest 2009), specially during the secondary stage of introduction (Mineur et al. 2008). However, this vector remains the largest unregulated vector for the introduction and spread of marine non-indgenous species (Clarke Murray et al. 2011).

Population genetic studies have revealed interesting patterns of introduction and spread via aquaculture. This vector is believed to account for as many introductions as shipping (Savini et al. 2000; Wolff and Reise 2002; Streftaris et al. 2005; Mineur et al. 2007). Contrary to the somewhat haphazard role of shipping, aquaculture is particularly prone to repeated introductions due to the continued interchange of species among facilities. For instance, the rapid spread of the gastropod Cyclope neritea along the French Atlantic coasts was shown to be associated with an admixture event between divergent genetic lineages, which increased genetic diversity in the newly recorded French populations (Fig. 3). Such a pattern is best explained by recurrent introductions from several areas in the Mediterranean Sea, including important shellfish culture sites in Spain, France and Italy (Simon-Bouhet et al. 2006). Another instance is the Japanese kelp Undaria pinnatifida, which is native to Asia and 
was first accidentally introduced in the Thau lagoon (French Mediterranean Sea) in the 1970s and subsequently intentionally transported to NE Atlantic shores to be cultivated. Genetic studies have shown that sustainable populations can be established after their escape from aquaculture facilities (e.g. in the English Channel, Grulois et al. 2011). The cultivated origin of wild populations of $U$. pinnatifida is supported by evidence that cultivated and wild populations belong to the same genetic lineage (Voisin et al. 2005). The escape and sustainable establishment of cultivated stocks has also been clearly demonstrated for the Pacific oyster Crassostrea gigas in Ireland (Kochmann et al. 2012). For both the Japanese kelp and the Pacific oyster, genetic data strongly suggest that wild populations have become self-sustainable. Another type of introduction derived from aquaculture activities concerns escapes of domesticated fish and their associated fauna, which in some cases has fully replaced native populations or have become introgressed with native populations (e.g. Glover et al. 2013). Such processes may, in addition, facilitate the translocation of non-indigenous pathogens to native species. This is exemplified by the large-scale infestation of the European eel Anguilla anguilla by the Asian parasite Anguillicola crassus. This is despite the fact that its original host (Anguilla japonica) has never successfully established in European waters (Wielgoss et al. 2008).

New regulations and international conventions aimed at controlling the transport of marine species (e.g. European Community No 708/2007 of $11^{\text {th }}$ June 2007 concerning the use of alien and locally absent species in aquaculture, or the new European Union 2020 Biodiversity Strategy that proposes a firm commitment to protect biodiversity and mitigate introduced species that threaten important economic activities) will contribute to the constraint of future introductions. However, it is uncertain how these measures will affect genetic patterns of non-indigenous species.

\section{Evolutionary outcomes}


As seen above, studies of successful marine non-indigenous species routinely report

the presence of populations with high genetic diversity in the introduced range. This situation may be linked to evolutionary neutral or selective processes. In the simplest case, all introduced genotypes establish and spread in the host environment, which can be similar to the native range. If the environment in the native and introduced range differs, phenotypic plasticity may be responsible for counteracting any effect of environmental filtering (Emerson and Gillespie 2008; Davidson et al. 2011). Phenotypic plasticity is a heritable trait that can accelerate adaptive processes (e.g. genetic assimilation Lande 2009; Fierst 2011). As introduced populations face important selective constraints and pressures over contemporary time scales (Huey et al. 2005), selection acting on the genetic background of introduced individuals is likely to be important (Novak 2007). In such cases, a central question arises: what are the evolutionary mechanisms based on selective processes that promote the sustainable and successful establishment of populations of non-indigenous species? Three possible explanations are proposed for selective processes occurring during the introduction of multiple divergent genotypes into a new range (Fig. 4).

The first scenario considers a situation whereby the introduced range receives introductions from divergent genetic backgrounds but only one of them establishes (p.eg. exclusion as a result of environmental filtering). The successful genotype may be better adapted to the new environment (often called 'pre-adapted' genotype, see Dlugosch and Parker 2007). This scenario requires some sort of match between conditions in the host environment and the evolutionary processes that occurred over long periods of time in the native range (Facon et al. 2006). This sitaution has been reported in some studies of marine systems. For instance, cryptic invasions by an introduced lineage were the most likely explanation for a new rapid expansion of Carcinus maenas along the NE Pacific shoreline (Roman 2006; Tepolt et al. 2009). This 'failure-success' scenario is difficult to prove without 
regular temporal surveys and specimen collections, including sampling from early or unsuccessful introductions. Museum collections and / or herbarium specimens (e.g. Lees et al. 2011) are of primary interest to resolve this point. Studies of failed introductions and monitoring invaders over time (e.g. survey of 'boom and bust' dynamics) are crucial for understanding long-term invasion dynamics (Suarez et al. 2005; Strayer et al. 2006; PérezPortela et al. 2012) although opportunities to study such events are rare.

The second possible scenario (Fig. 4) involves selection forces that affect the standing genetic variation (i.e. pre-existing polymorphisms) introduced from the native range. This scenario mimics a situation often encountered in marine invertebrates with: 1) high genetic diversity and little genetic structure in the native range, and 2) high propagule pressure following the introduction process. Interestingly, scenario 2 differs from scenario 1 in that introductions from isolated regions of the native range are not required. Introduction may simply occur from a genetically polymorphic source, and subsequently selection (e.g. through competition and predation) would follow. Selection on pre-existing polymorphisms may operate over short time scales compared to selection on new mutations (Barrett and Schluter 2008; Vandepitte et al. 2014). The genetic variants on which selection operates in the introduced range may be neutral or even slightly deleterious in the native range but confer some advantage to the introduced individuals in their new environment. Genome scans are appropriate methods to detect loci influenced by selection processes (i.e. outliers) in the absence of knowledge about the genes and traits that may be under selection (Bierne et al. 2011). Using such an approach, Riquet et al. (2013) did not find any outlier loci when comparing native American and introduced European populations of the slipper limpet $C$. fornicata, while their study revealed outliers between populations in the native range. This outcome suggests that either no selection on standing genetic variation occurred following the introduction process or, simply, that genome scans, particularly when using a low number of 
markers, may not be efficient for identifying selection during colonisation because of the short time elapsed since the introduction. In contrast, Rohfritsch et al. (2013) showed the existence of outlier loci in introduced European populations of the Pacific oyster C. gigas. Two groups of populations were identified based on some of the outliers, but such genetic structure was uncorrelated with the one observed from neutral loci. While the authors did not fully exclude the effect of secondary multiple introductions, they suggested that parallel adaptations occurred in similar environments (in this case fjord-like environments). The two examples detailed above advocate for further investigation of the adaptive genomic architecture of native and introduced populations.

The last selective evolutionary scenario (Fig. 4) is based on the idea that new adaptive genetic combinations could arise from intraspecific crosses among individuals characterized by different genetic backgrounds (Facon et al. 2008; Lawson Handley et al. 2011). Similarly to interspecific hybridisation (Ellstrand and Schierenbeck 2000; Seehausen 2004; de Carvalho et al. 2013), genetic admixture may create novel allelic combinations that enhance the fitness of introduced individuals. The underlying rationale is that new heritable traits arise because of novel genetic combinations and that selection operates on these new traits (Rius and Darling 2014). In the same way as heterosis (or hybrid vigour) among interspecific lineages operates (e.g. Drake 2006), strong evidence of correlation between genetic admixture and fitness of introduced individuals has been shown (e.g. Kolbe et al. 2007; Turgeon et al. 2011). Although the consequences of genetic admixture of divergent genotypes have been rarely studied in marine systems, studies reporting genetic admixture in introduced populations are proliferating. Pineda et al. (2011) found an excess of admixed genotypes of two nuclear lineages in introduced populations of the ascidian Styela plicata, which suggests that selection favours novel genetic combinations. Similarly, introduced populations of other widespread ascidian species show genetic admixture of divergent lineages (Rius et al. 2012; Zhan et al. 
2012). However, this does not necessarily mean that admixed genotypes are always favoured in the introduced range, as the predominance of unadmixed genotypes has also been reported (Ordóñez et al. 2013).

Taken together, pre-adaption, selection on standing genetic variation and genetic novelties arising from post-immigration genetic admixture can be important drivers influencing evolutionary outcomes. Further research should yield important insights about these mechanisms in marine introductions.

\section{Concluding remarks and future directions}

Studies on marine invasion genetics have generally shown that introduced populations rarely suffer from founder effects and are characterized by high genetic diversity, most likely as a result of repeated introductions and high propagule pressure. Despite almost 20 years of research, our study suggest that marine invasion genetics is still in its infancy. Most studies in European seas have focussed on cryptic diversity and descriptive comparisons of genetic composition and structure, from which insights into introduction patterns (pathways, sources, connectivity, etc.) have been drawn. However, little information is available on the underlying evolutionary mechanisms involved in marine biological invasions.

The currently limited genetic information of marine non-indigenous species makes the link between genetic information and rapid adaptation, phenotypic plasticity or fitness, elusive. The lack of comprehensive associations between genetic diversity and the success of marine biological invasions also brings into question the plausibility of using neutral genetic diversity as a proxy for adaptive genetic diversity and colonisation success (Hansen et al. 2012). The patterns observed to date advocate for further investigation of genetic and genomic architecture of marine non-indigenous species as well as in-depth analyses of the link between genotypes and phenotypes, considering in particular the fitness and adaptive potential of admixed genotypes. 
Key concerns such as the introduction history and the traits that determine invasiveness of non-indigenous species may benefit immensely from major advances in molecular biology and bioinformatics. Issues related to phylogeny and identification, historical and contemporaneous sources of non-indigenous species, population characteristics, and potential or realised adaptation can be tackled through an increasingly sophisticated analytical toolbox (reviews by Allendorf et al. 2010; Cock et al. 2010; Angeloni et al. 2012). The advent of next generation sequencing techniques (NGS) has revolutionized the potential for genetic and phenotypic analyses of the invasion process in non-model organisms. New markers such as single nucleotide polymorphisms (SNPs) can be easily developed from sequence data of full or partial genomes or transcriptomes (Everett et al. 2011; Helyar et al. 2011; Seeb et al. 2011; Reitzel et al. 2013). They allow for precise population genetic analyses, while at the same time allowing for the detection of adaptive changes through the study of outlier loci with non-neutral behaviour (Stapley et al. 2010; Rohfritsch et al 2013). NGS methods allow the study of hybridisation patterns of sibling species in secondary contact zones (e.g. Blank et al. 2012). They also enable the study of global gene expression patterns through so-called RNA-seq techniques (Wang et al. 2009; Wolf 2013), which can highlight differential expression levels of key genes as a response to new conditions in the introduced range. NGS techniques are also being increasingly used in the study of environmental DNA for several applications (Bohmann et al. 2014). Among these, environmental DNA can be a powerful tool for the early detection of introduced species, even before they become conspicuous in new localities (Bott et al. 2010; Bucklin et al. 2011). Another promising technique involves the sequencing of ancient DNA and historical (often low quality) DNA, which is highly applicable to museum collections that harbour alien taxa (e.g. Roman 2006; Lees et al. 2011). Finally, it is increasingly recognized that epigenetics, the study of heritable changes in gene expression and function that cannot be explained by changes in DNA 
sequence, affects the phenotype and hence the potential to adapt. This happens through changes in the DNA methylation status, remodelling of chromatin structure and the regulation of expression mediated by microRNA (Bossdorf et al. 2008 and references therein). Such routes have yet to be explored in marine non-indigenous species, but may provide the key to understanding illusive factors affecting invasiveness.

Overall, the combination of genome-, transcriptome- and proteome-based methods will increasingly facilitate the investigation of a large set of issues in biological invasion studies; from the identification of non-indigenous species to the disentangling of the roles of phenotypic adaptation versus evolutionary change in the success of introductions. Much remains to be done in order for molecular techniques to become fully implemented in invasion genetics, especially with regards to describing and understanding the evolutionary mechanisms involved in the invasion process in marine ecosystems. 


\section{Acknowledgements}

The authors are grateful to Benoit Simon-Bouhet and Florentine Riquet for providing data and assistance in the design of some figures. We thank Stefano Piraino and the European FP7 project VECTORS (Vectors of Change in Oceans and Seas Marine Life, Impact on Economic Sectors, grant agreement \#266445) for the invitation to the international workshop entitled Molecular Tools for Monitoring Marine Invasive Species. We are grateful to the reviewers who provided comments that greatly improved the manuscript. Funding has also been provided by the European Union FP7 project COCONET ( $7^{\text {th }}$ PM, \#287844). FVi acknowledges the HiFlo (ANR-08-BLAN-0334) and HySea (ANR-12-BSV7-0011) ANR programmes for data and inspiration. XT is grateful to the Spanish Ministry of Science project CTM2010-22218 for funding. 


\section{References}

Acosta H, Forrest BM (2009) The spread of marine non-indigenous species via recreational boating: A conceptual model for risk assessment based on fault tree analysis. Ecol Mod 220:1586-1598

Allendorf FW, Hohenlohe PA, Luikart G (2010) Genomics and the future of conservation genetics. Nature Rev Genet 11:697-709

Angeloni F, Wagemaker N, Vergeer P, et al. (2012) Genomic toolboxes for conservation biologists. Evol Appl 5:130-143

Appeltans W, Ahyong ST, Anderson G, et al. (2012) The magnitude of global marine species diversity. Curr Biol 22:2189-202

Audzijonyte A, Haugstetter J, Arbačiauskas K (2013) Characterization of ten polymorphic microsatellite markers in an invasive Ponto-Caspian mysid crustacean Paramysis lacustris. Conserv Genet Res 6:309-311

Audzijonyte A, Wittmann KJ, Väinölä R (2007) Tracing recent invasions of the PontoCaspian mysid shrimp Hemimysis anomala across Europe and to North America with mitochondrial DNA. Diversity Distrib 14:179-186

Ayre DJ, Minchinton TE, Perrin C (2009) Does life history predict past and current connectivity for rocky intertidal invertebrates across a marine biogeographic barrier? Mol Ecol 18:1887-1903

Azzurro E, Golani D, Bucciarelli G, et al. (2006) Genetics of the early stages of invasion of the Lessepsian rabbitfish Siganus luridus. JEMBE 333:190-201

Balanyà J, Segarra C, Prevosti A, et al. (1994) Colonization of America by Drosophila subobscura: The founder event and a rapid expansion. J Hered 85:427-432

Barrett RD, Schluter D (2008) Adaptation from standing genetic variation. TREE 23:38-44

Belmaker J, Parravicini V, Kulbicki M (2013) Ecological traits and environmental affinity explain Red Sea fish introduction into the Mediterranean. Global Chang Biol 19:13731382

Bernardi G, Golani D, Azzurro E (2010) The genetics of Lessepsian bioinvasions. In: Golani D and Applebaum-Golani B (eds) Fish invasions of the Mediterranean Sea: change and renewal. Pensoft Publishers, Sofia, pp. 71-84

Bierne N, Welch J, Loire E, et al. (2011) The coupling hypothesis: why genome scans may fail to map local adaptation genes. Mol Ecol 20:2044-72

Blackburn TM, Pysek P, Bacher S, et al. (2011) A proposed unified framework for biological invasions. TREE 26:333-339

Blank M, Bastrop R (2009) Phylogeny of the mud worm genus Marenzelleria (Polychaeta, Spionidae) inferred from mitochondrial DNA sequences. Zool Scri 38:313-321

Blank M, Mikkat S, Verleih M, et al. (2012) Proteomic comparison of two invasive polychaete species and their naturally occurring F1-hybrids. J Prot Res 11:897-905

Bock DG, MacIsaac HJ, Cristescu ME (2012) Multilocus genetic analyses differentiate between widespread and spatially restricted cryptic species in a model ascidian. Proc Roy Soc Biol Sci 279:2377-85

Bock DG, Zhan A, Lejeusne C, et al. (2011) Looking at both sides of the invasion: patterns of colonization in the violet tunicate Botrylloides violaceus. Mol Ecol 20:503-516

Bohmann K, Evans A, Gilbert MT, et al. (2014) Environmental DNA for wildlife biology and biodiversity monitoring. TREE 29: 358-367

Bolte S, Fuentes V, Haslob H, et al. (2013) Population genetics of the invasive ctenophore Mnemiopsis leidyi in Europe reveal source-sink dynamics and secondary dispersal to the Mediterranean Sea. MEPS 485:25-36 
Bossdorf O, Richards CL, Pigliucci M (2008) Epigenetics for ecologists. Ecol Lett 11:106115

Bott NJ, Ophel-Keller KM, Sierp MT, et al. (2010) Toward routine, DNA-based detection methods for marine pests. Biotech Adv 28:706-14

Briski E, Bailey SA, Casas-Monroy O, et al. (2012) Relationship between propagule pressure and colonization pressure in invasion ecology: a test with ships' ballast. Proc Roy Soc Biol Sci 279:2990-7

Brown JE, Stepien CA (2008) Ancient divisions, recent expansions: phylogeography and population genetics of the round goby Apollonia melanostoma. Mol Ecol 17:25982615

Bucklin A, Steinke D, Blanco-Bercial L (2011) DNA Barcoding of Marine Metazoa. Ann Rev Mar Sci 3:471-508

Bulleri F, Airoldi L (2005) Artificial marine structures facilitate the spread of a nonindigenous green alga, Codium fragile ssp. tomentosoides, in the north Adriatic Sea. J Appl Ecol 42:1063-1072

Cadotte MW, Hamilton MA, Murray BR (2009) Phylogenetic relatedness and plant invader success across two spatial scales. Diversity Distrib 15:481-488

Callaway RM, Maron JL (2006) What have exotic plant invasions taught us over the past 20 years? TREE 21:369-374

Carlton JT (1996) Pattern, process, and prediction in marine invasion ecology. Biol Conserv 78:97-106

Carlton JT (2000) Quo vadimus exotica oceanica? Marine bioinvasion ecology in the twentyfirst century. In: Pederson J (ed) Marine Bioinvasions: Proceedings of the First National Conference. Massachusetts Institute of Technology Sea Grant College Program Cambridge pp. 6-23

Carlton JT (2001) Introduced species in US coastal waters: environmental impacts and management priorities. Pew Oceans Commission, Arlington, Virginia

Carlton JT (2009) Deep Invasion Ecology and the Assembly of Communities in Historical Time. In: Rilov G and Crooks JA (eds) Biological Invasions in Marine Ecosystems. Springer-Verlag, Berlin Heidelberg, pp. 13-56

Carlton JT, Geller JB (1993) Ecological roulette: the global transport of nonindigenous marine organisms. Science 261:78-82

Ciosi M, Miller NJ, Toepfer S, et al. (2011) Stratified dispersal and increasing genetic variation during the invasion of Central Europe by the western corn rootworm, Diabrotica virgifera virgifera. Evol Appl 4:54-70

Clarke Murray C, Pakhomov EA, Therriault TW (2011) Recreational boating: a large unregulated vector transporting marine invasive species. Diversity Distrib 17:11611172

Cock JM, Tessmar-Raible K, Boyen C, et al. (2010) Introduction to Marine Genomics. Springer

Cohen AN, Carlton JT (1998) Accelerating invasion rate in a highly invaded estuary. Science 279:555-558

Coll M, Piroddi C, Steenbeck J, et al. (2010) The biodiversity of the Mediterranean Sea: Estimates, patterns and threats. PLoS One 5:e11842

Coutts ADM, Dodgshun TJ (2007) The nature and extent of organisms in vessel sea-chests: A protected mechanism for marine bioinvasions. Mar Pollut Bul 54:875-886

Cristescu ME, Witt JD, Grigorovich IA, et al. (2004) Dispersal of the Ponto-Caspian amphipod Echinogammarus ischnus: invasion waves from the Pleistocene to the present. Heredity 92:197-203 
Cristescu MEA, Hebert PDN (2005) The "Crustacean Seas" - an evolutionary perspective on the Ponto Caspian peracarids. Can J Fish Aquat Sci 62:505-517

Crooks JA (2005) Lag times and exotic species: The ecology and management of biological invasions in slow-motion. Ecoscience 12:316-329

Dafforn KA, Johnston EL, Glasby TM (2009) Shallow moving structures promote marine invader dominance. Biofouling 25:277-287

Daguin C, Borsa P (2000) Genetic relationships of Mytilus galloprovincialis Lamarck populations worldwide: evidence from nuclear-DNA markers. Geological Society, London, Special Publications 177:389-397

Davidson AM, Jennions M, Nicotra AB (2011) Do invasive species show higher phenotypic plasticity than native species and, if so, is it adaptive? A meta-analysis. Ecol Lett 14:419-31

Davies B, Villablanca FX, Roderick GK (1999) Bioinvasions of the medfly Ceratitis capitata: source estimation using DNA Sequences at multiple intron loci. Genetics 153:351-360

Dawson MN, Hamner WM (2005) Rapid evolutionary radiation of marine zooplankton in peripheral environments. PNAS 102:9235-40

de Carvalho JF, Poulain J, Da Silva C, et al. (2013) Transcriptome de novo assembly from next-generation sequencing and comparative analyses in the hexaploid salt marsh species Spartina maritima and Spartina alterniflora (Poaceae). Heredity 110:181-193

Dlugosch KM, Parker IM (2007) Molecular and quantitative trait variation across the native range of the invasive species Hypericum canariense: evidence for ancient patterns of colonization via pre-adaptation? Mol Ecol 16:4269-83

Drake JM (2006) Heterosis, the catapult effect and establishment success of a colonizing bird. Biol Lett 2:304-307

Dupont L, Ellien C, Viard F (2007a) Limits to gene flow in the slipper limpet Crepidula fornicata as revealed by microsatellite data and a larval dispersal model. MEPS 349:125-138

Dupont L, Jollivet D, Viard F (2003) High genetic diversity and ephemeral drift effects in a successful introduced mollusc (Crepidula fornicata: Gastropoda). MEPS 253:183-195

Dupont L, Viard F, David P, et al. (2007b) Combined effects of bottlenecks and selfing in populations of Corella eumyota, a recently introduced sea squirt in the English Channel. Diversity Distrib 13:808-817

Ellstrand NC, Schierenbeck KA (2000) Hybridization as a stimulus for the evolution of invasiveness in plants? PNAS 97:7043-7050

Emerson BC, Gillespie RG (2008) Phylogenetic analysis of community assembly and structure over space and time. TREE 23:619-630

Estoup A, Guillemaud T (2010) Reconstructing routes of invasion using genetic data: why, how and so what? Mol Ecol 19:4113-4130

Everett MV, Grau ED, Seeb JE (2011) Short reads and nonmodel species: exploring the complexities of next-generation sequence assembly and SNP discovery in the absence of a reference genome. Mol Ecol Res 11:93-108

Facon B, Genton BJ, Shykoff J, et al. (2006) A general eco-evolutionary framework for understanding bioinvasions. TREE 21:130-135

Facon B, Pointier JP, Jarne P, et al. (2008) High genetic variance in life-history strategies within invasive populations by way of multiple introductions. Curr Biol 18:363-367

Feldheim KA, Willink P, Brown JE, et al. (2009) Microsatellite loci for Ponto-Caspian gobies: markers for assessing exotic invasions. Mol Ecol Res 9:639-644

Fierst JL (2011) A history of phenotypic plasticity accelerates adaptation to a new environment. J Evol Biol 24:1992-2001 
Forrest BM, Gardner JPA, Taylor MD (2009) Internal borders for managing invasive marine species. J Appl Ecol 46:46-54

Frankham R (2005) Resolving the genetic paradox in invasive species. Heredity 94:385

Fuller P, Benson A, Maynard E, et al. (2014) Neogobius melanostomus. USGS Nonindigenous Aquatic Species Database. Gainesville, FL,

Gaither MR, Toonen RJ, Bowen BW (2012) Coming out of the starting blocks: extended lag time rearranges genetic diversity in introduced marine fishes of Hawai'i. Proc Roy Soc Biol Sci 279:3948-57

Galil BS (2007) Loss or gain? Invasive aliens and biodiversity in the Mediterranean Sea. Mar Pollut Bul 55:314-322

Galil BS (2009) Taking stock: inventory of alien species in the Mediterranean Sea. Biol Invasions 11:359-372

Galil BS (2012) Truth and consequences: the bioinvasion of the Mediterranean Sea. Integr Zool 7:299-311

Geller JB, Darling JA, Carlton JT (2010) Genetic perspectives on marine biological invasions. Ann Rev Mar Sci 2:367-393

Ghabooli S, Shiganova TA, Briski E, et al. (2013) Invasion pathway of the ctenophore Mnemiopsis leidyi in the Mediterranean Sea. PLoS One 8:e81067

Ghabooli S, Shiganova TA, Zhan A, et al. (2011) Multiple introductions and invasion pathways for the invasive ctenophore Mnemiopsis leidyi in Eurasia. Biol Invasions 13:679-690

Gianguzza P, Agnetta D, Bonaviri C, et al. (2011) The rise of thermophilic sea urchins and the expansion of barren grounds in the Mediterranean Sea. Chem Ecol 27:129-134

Glover KA, Pertoldi C, Besnier F, et al. (2013) Atlantic salmon populations invaded by farmed escapees: quantifying genetic introgression with a Bayesian approach and SNPs. BMC Genetics 14:74

Golani D, Azzuro E, Corsini-Foka M, et al. (2007) Genetic bottlenecks and successful biological invasions: the case of a recent Lessepsian migrant. Biol Lett 3:541-545

Golani D, Ritte U (1999) Genetic relationship in goatfishes (Mullidae: Perciformes) of the Red Sea and the Mediterranean, with remarks on Suez Canal migrants. Sci Mar 63:129-135

Goldstien SJ, Dupont L, Viard F, et al. (2011) Global phylogeography of the widely introduced north west Pacific ascidian Styela clava. PLoS ONE 6:e16755

Gollasch S (1996) Untersuchungen des Arteintrages durch den internationalen Schiffsverkehr unter besonderer Berücksichtigung nichtheimischer Arten. PhD, University of Hamburg, Germany

Gollasch S, Lenz J, Dammer M, et al. (2000) Survival of tropical ballast water organisms during a cruise from the Indian Ocean to the North Sea. J Plankt Res 22:923-937

Gregg MC, Özsoy E (2002) Flow, water mass changes, and hydraulics in the Bosphorus. J Geoph Res 107:1-23

Grosholz E (2002) Ecological and evolutionary consequences of coastal invasions. TREE $17: 22-27$

Grulois D, Leveque L, Viard F (2011) Mosaic genetic structure and sustainable establishment of the invasive kelp Undaria pinnatifida within a bay (Bay of St-Malo, Brittany). Cah Biol Mar 52:485-498

Hansen MM, Olivieri I, Waller DM, et al. (2012) Monitoring adaptive genetic responses to environmental change. Mol Ecol 21:1311-29

Hassan M, Bonhomme F (2005) No reduction in neutral variability of mitochondrial and nuclear genes for a Lessepsian migrant, Upeneus moluccensis. J Fish Biol 66:865-870 
Hassan M, Harmelin-Vivien M, Bonhomme F (2003) Lessepsian invasion without bottleneck: example of two rabbitfish species (Siganus rivulatus and Siganus luridus). JEMBE 291:219-232

Haydar D (2012) What is natural? The scale of cryptogenesis in the North Atlantic Ocean. Diversity Distrib 18:101-110

Helyar SJ, Hemmer-Hansen J, Bekkevold D, et al. (2011) Application of SNPs for population genetics of nonmodel organisms: new opportunities and challenges. Mol Ecol Res $11: 123-36$

Hendry AP, Kinnison MT (2001) An introduction to microevolution: rate, pattern, process. Genetica 112-113:1-8

Holland BS (2000) Genetics of marine bioinvasions. Hydrobiologia 420:63-71

Hollebone AL, Hay ME (2007) Propagule pressure of an invasive crab overwhelms native biotic resistance. MEPS 342:191-196

Huey RB, Gilchrist GW, Hendry AP (2005) Using invasive species to study evolution: case studies with Drosophila and salmon. In: Sax DF, Stachowicz JJ and Gaines SD (eds) Species Invasions: Insights into Ecology, Evolution, and Biogeography. Sinauer Associates Inc., Sunderland, Massachusetts, pp. 139-164

Kaluza P, Kölzsch A, Gastner MT, et al. (2010) The complex network of global cargo ship movements. J Roy Soc Interf 7:1093-1103

Keller RP, Drake JM, Drew MB, et al. (2011) Linking environmental conditions and ship movements to estimate invasive species transport across the global shipping network. Diversity Distrib 17:93-102

Keller SR, Taylor DR (2010) Genomic admixture increases fitness during a biological invasion. J Evol Biol 23:1720-1731

Kelly DW, Muirhead JR, Heath DD, et al. (2006) Contrasting patterns in genetic diversity following multiple invasions of fresh and brackish waters. Mol Ecol 15:3641-53

Kelly RP, Palumbi SR (2010) Genetic structure among 50 species of the northeastern Pacific rocky intertidal community. PLoS One 5:e8594

Kochmann J, Carlsson J, Crowe TP, et al. ( 2012) Genetic evidence for the uncoupling of local aquaculture activities and a population of an invasive species - a case study of Pacific oysters (Crassostrea gigas). J Heredity 103:661-671

Kolar CS, Lodge DM (2001) Progress in invasion biology: predicting invaders. TREE 16:199-204

Kolbe JJ, Larson A, Losos JB (2007) Differential admixture shapes morphological variation among invasive populations of the lizard Anolis sagrei. Mol Ecol 16:1579-91

Koskinen MT, Sundell P, Piironen J, et al. (2002) Genetic assessment of spatiotemporal evolutionary relationships and stocking effects in grayling (Thymallus thymallus, Salmonidae). Ecol Lett 5:193-205

Lande R (2009) Adaptation to an extraordinary environment by evolution of phenotypic plasticity and genetic assimilation. J Evol Biol 22:1435-46

Lawson Handley LJ, Estoup A, Evans DM, et al. (2011) Ecological genetics of invasive alien species. BioControl 56:409-428

Lee CE (2002) Evolutionary genetics of invasive species. TREE 17:386-391

Lees DC, Lack HW, Rougerie R, et al. (2011) Tracking origins of invasive herbivores through herbaria and archival DNA: the case of the horse-chestnut leaf miner. Front Ecol Environ 9:322-328

Lejeusne C, Chevaldonné P, Pergent-Martini C, et al. (2010) Climate change effects on a miniature ocean: the highly diverse, highly impacted Mediterranean Sea. TREE $25: 250-260$ 
Leppa $\square$ koski E, Gollasch S, Gruszka P, et al. (2002) The Baltic - a sea of invaders. Can J Fish Aquat Sci 59:1175-1188

Leung B, Drake JM, Lodge DM (2004) Predicting invasions: propagule pressure and the gravity of Allee effects. Ecology 85:1651-1660

Meimberg H, Milan NF, Karatassiou M, et al. (2010) Patterns of introduction and adaptation during the invasion of Aegilops triuncialis (Poaceae) into Californian serpentine soils. Mol Ecol 19:5308-19

Menge BA, Chan F, Dudas S, et al. (2009) Do terrestrial ecologists ignore aquatic literature? Front Ecol Environ 7:182-183

Mineur F, Belsher T, Johnson MP, et al. (2007) Experimental assessment of oyster transfers as a vector for macroalgal introductions. Biol Conserv 137:237-247

Mineur F, Cook EJ, Minchin D, et al. (2012) Changing coasts: marine aliens and artificial structures. Oceanogr Mar Biol Ann Rev 50:189-234

Mineur F, Johnson MP, Maggs CA (2008) Macroalgal introductions by hull fouling on recreational vessels: seaweeds and sailors. Environ Manag 42:667-76

Murray JW, Top Z, Özsoy E (1991) Hydrographic properties and ventilation of the Black Sea. Deep Sea Res 38:S663-S689

Neilson ME, Stepien CA (2011) Historic speciation and recent colonization of Eurasian monkey gobies (Neogobius fluviatilis and N. pallasi) revealed by DNA sequences, microsatellites, and morphology. Diversity Distrib 17:688-702

Norkko J, Reed DC, Timmermann K, et al. (2012) A welcome can of worms? Hypoxia mitigation by an invasive species. Global Chang Biol 18:422-434

Novak SJ (2007) The role of evolution in the invasion process. PNAS 104:3671-3672

Ordóñez V, Pascual M, Rius M, et al. (2013) Mixed but not admixed: A spatial analysis of genetic variation of an invasive ascidian on natural and artificial substrates. Mar Biol 160:1645-1660

Patarnello T, Volckaert FAMJ, Castilho R (2007) Pillars of Hercules: is the AtlanticMediterranean transition a phylogeographical break? Mol Ecol 16:4426-4444

Patti FP, Gambi MC (2001) Phylogeography of the invasive polychaete Sabella spallanzanii (Sabellidae) based on the nucleotide sequence of internal transcribed spacer 2 (ITS2) of nuclear rDNA. MEPS 215:169-177

Pérez-Portela R, Arranz V, Rius M, et al. (2013) Cryptic speciation or global spread? The case of a cosmopolitan marine invertebrate with limited dispersal capabilities. Sci Rep 3:3197

Pérez-Portela R, Turon X, Bishop JDD (2012) Bottlenecks and loss of genetic diversity: spatio-temporal patterns of genetic structure in an ascidian recently introduced in Europe. MEPS 451:93-105

Pineda MC, López-Legentil S, Turon X (2011) The whereabouts of an ancient wanderer: global phylogeography of the solitary ascidian Styela plicata. PLoS ONE 6:e25495

Provan J, Murphy S, Maggs CA (2005) Tracking the invasive history of the green alga Codium fragile ssp. tomentosoides. Mol Ecol 14:189-94

Reitzel AM, Herrera S, Layden MJ, et al. (2013) Going where traditional markers have not gone before: utility of and promise for RAD sequencing in marine invertebrate phylogeography and population genomics. Mol Ecol 22:2953-70

Reusch TB, Bolte S, Sparwel M, et al. (2010) Microsatellites reveal origin and genetic diversity of Eurasian invasions by one of the world's most notorious marine invader, Mnemiopsis leidyi (Ctenophora). Mol Ecol 19:2690-2699

Reuschel S, Cuesta JA, Schubart CD (2010) Marine biogeographic boundaries and human introduction along the European coast revealed by phylogeography of the prawn Palaemon elegans. Mol Phylogenet Evol 55:765-75 
Riquet F, Daguin-Thiebaut C, Ballenghien M, et al. (2013) Contrasting patterns of genomewide polymorphism in the native and invasive range of the marine mollusc Crepidula fornicata. Mol Ecol 22:1003-1018

Rius M, Clusella-Trullas S, McQuaid CD, et al. (2014) Range expansions across ecoregions: interactions of climate change, physiology and genetic diversity. Global Ecol Biogeogr 23:76-88

Rius M, Darling JA (2014) How important is intraspecific genetic admixture to the success of colonising populations? TREE 29:233-242

Rius M, Shenkar N (2012) Ascidian introductions through the Suez Canal: The case study of an Indo-Pacific species. Mar Pollut Bul 64:2060-2068

Rius M, Teske PR (2013) Cryptic diversity in coastal Australasia: a morphological and mitonuclear genetic analysis of habitat-forming sibling species. Zool J Linn Soc 168:597-611

Rius M, Turon X, Ordóñez V, et al. (2012) Tracking invasion histories in the sea: facing complex scenarios using multilocus data. PLoS ONE 7:e35815

Rohfritsch A, Bierne N, Boudry P, et al. (2013) Population genomics shed light on the demographic and adaptive histories of European invasion in the Pacific oyster, Crassostrea gigas. Evol Appl 6:1064-1078

Roman J (2006) Diluting the founder effect: cryptic invasions expand a marine invader's range. Proc Roy Soc Biol Sci 273:2453-2459

Roman J, Darling JA (2007) Paradox lost: genetic diversity and the success of aquatic invasions. TREE 22:454-464

Roman J, Palumbi SR (2004) A global invader at home: population structure of the green crab, Carcinus maenas, in Europe. Mol Ecol 13:2891-2898

Ruiz GM, Fofonoff PW, Carlton JT, et al. (2000) Invasion of coastal marine communities in North America: apparent patterns, processes, and biases. AREES 31:481-531

Sanna D, Merella P, Lai T, et al. (2011) Combined analysis of four mitochondrial regions allowed the detection of several matrilineal lineages of the lessepsian fish Fistularia commersonii in the Mediterranean Sea. J Mar Biol Ass UK 91:1289-1293

Savini D, Occhipinti-Ambrogi A, Marchini A, et al. (2000) The top 27 animal alien species introduced into Europe for aquaculture and related activities. J Appl Ichthy 26:1-7

Scammell GV (1981) The world encompassed: the first European maritime empires c. 8001650. University of California Press

Scammell GV (1991) The first imperial age: European overseas expansion 1500-1715. Routledge

Seeb JE, Carvalho G, Hauser L, et al. (2011) Single-nucleotide polymorphism (SNP) discovery and applications of SNP genotyping in nonmodel organisms. Mol Ecol Res $11: 1-8$

Seehausen O (2004) Hybridization and adaptive radiation. TREE 19:198-207

Selkoe KA, Toonen RJ (2011) Marine connectivity: a new look at pelagic larval duration and genetic metrics of dispersal. MEPS 436:291-305

Serrano E, Coma R, Ribes M, et al. (2013) Rapid northward spread of a zooxanthellate coral enhanced by artificial structures and sea warming in the western Mediterranean. PLoS One 8:e52739

Shanks AL (2009) Pelagic larval duration and dispersal distance revisited. Biol Bul 216:373385

Siegel DA, Kinlan BP, Gaylord B, et al. (2003) Lagrangian descriptions of marine larval dispersion. MEPS 260:83-96

Simberloff D (2009) The role of propagule pressure in biological invasions. AREES 40:81102 
Simon-Bouhet B, Garcia-Meunier P, Viard F (2006) Multiple introductions promote range expansion of the mollusc Cyclope neritea (Nassariidae) in France: evidence from mitochondrial sequence data. Mol Ecol 15:1699-1711

Sorokin II (2002) The Black Sea: ecology and oceanography, Backhuys

Stapley J, Reger J, Feulner PG, et al. (2010) Adaptation genomics: the next generation. TREE 25:705-12

Strayer DL, Eviner VT, Jeschke JM, et al. (2006) Understanding the long-term effects of species invasions. TREE 21:645-651

Streftaris N, Zenetos A (2006) Alien Marine Species in the Mediterranean - the 100 'Worst Invasives' and their Impact. Medit Mar Sci 7:87-118

Streftaris N, Zenetos A, Papathanassiou E (2005) Globalisation in marine ecosystems: the story of non-indigenous marine species across European Seas. Oceanogr Mar Biol Ann Rev 43:419-453

Suarez AV, Holway DA, Ward PS (2005) The role of opportunity in the unintentional introduction of nonnative ants. PNAS 102:17032-17035

Taylor CM, Hastings A (2005) Allee effects in biological invasions. Ecol Lett 8:895-908

Taylor DR, Keller SR (2007) Historical range expansion determines the phylogenetic diversity introduced during contemporary species invasion. Evolution 61:334-45

Tepolt CK, Darling JA, Bagley MJ, et al. (2009) European green crabs (Carcinus maenas) in the northeastern Pacific: genetic evidence for high population connectivity and current-mediated expansion from a single introduced source population. Diversity Distrib 15:997-1009

Tsutsui ND, Suarez AV, Holway DA, et al. (2000) Reduced genetic variation and the success of an invasive species. PNAS 97:5948-5953

Turgeon J, Tayeh A, Facon B, et al. (2011) Experimental evidence for the phenotypic impact of admixture between wild and biocontrol Asian ladybird (Harmonia axyridis) involved in the European invasion. J Evol Biol 24:1044-52

Uriz MJ, Turon X (2012) Sponge ecology in the molecular era. Advances in Mar Biol 61:345410

Vandepitte K, de Meyer T, Helsen K, et al. (2014) Rapid genetic adaptation precedes the spread of an exotic plant species. Mol Ecol 23:2157-64

Viard F, Ellien C, Dupont L (2006) Dispersal ability and invasion success of Crepidula fornicata in a single gulf: insights from genetic markers and larval-dispersal model. Helg Mar Res 60:144-152

Villablanca FX, Roderick GK, Palumbi SR (1998) Invasion genetics of the Mediterranean fruit fly: variation in multiple nuclear introns. Mol Ecol 7:547-560

Voisin M, Engel CR, Viard F (2005) Differential shuffling of native genetic diversity across introduced regions in a brown alga: aquaculture vs. maritime traffic effects. PNAS 102:5432-5437

Wang Z, Gerstein M, Snyder M (2009) RNA-Seq: a revolutionary tool for transcriptomics. Nature Rev Genet 10:57-63

Weersing K, Toonen RJ (2009) Population genetics, larval dispersal, and connectivity in marine systems. MEPS 393:1-12

Wielgoss S, Taraschewski H, Meyer A, et al. (2008) Population structure of the parasitic nematode Anguillicola crassus, an invader of declining North Atlantic eel stocks. Mol Ecol 17:3478-95

Wilson JRU, Dormontt EE, Prentis PJ, et al. (2009) Something in the way you move: dispersal pathways affect invasion. TREE 24:136-144

Wolf JBW (2013) Principles of transcriptome analysis and gene expression quantification: an RNA-seq tutorial. Mol Ecol Res 13:559-572 
Wolff WJ, Reise K (2002) Oyster imports as a vector for the introduction of alien species into northern and western european coastal waters. In: Leppäkoski E, Gollasch S and Olenin S (eds) Invasive aquatic species of Europe. Distribution, impacts and management. Kluwer Academic Publishers, Dordrecht / Boston / London, pp. 193-205

Yaltırak C, Alpar B, Sakınç M, et al. (2000) Origin of the Strait of Çanakkale (Dardanelles): regional tectonics and the Mediterranean-Marmara incursio. Mar Geol 164:139-156

Zenetos A, Gofas S, Morri C, et al. (2012) Alien species in the Mediterranean Sea by 2012. A contribution to the application of European Union's Marine Strategy Framework Directive (MSFD). Part 2. Introduction trends and pathways. Medit Mar Sci 13:328352

Zhan A, Darling JA, Bock DG, et al. (2012) Complex genetic patterns in closely related colonizing invasive species. Ecol Evol 2:1331-1346

Zhan A, Macisaac HJ, Cristescu ME (2010) Invasion genetics of the Ciona intestinalis species complex: from regional endemism to global homogeneity. Mol Ecol 19:4678-4694 


\section{Figures captions}

Fig. 1. Genetic studies of marine biological invasions that include samples from European seas (see Table S1 for details). A) Number of studies over time, B) Number of studies per region, C) Number of species analysed genetically (white bars and left $\mathrm{Y}$-axis, note that estimates are conservative: species complexes are considered as a single species, and multispecies works with no clear indication of the non-indigenous status of the species have been excluded) and number of introduced species reported [black bars and right Y-axis, using Zenetos et al. (2012) as a reference], D) Outcome of studies that compare patterns of genetic diversity between native and introduced populations, categorized by offspring dispersal capabilities (short or long, above) and the presence / absence of evidence for multiple introductions (below).

Fig. 2. Genetic diversity using: A) 17 microsatellites and B) 327 AFLP loci from native (black bars; NW Atlantic) and introduced (white bars; Mediterranean Sea, NE Atlantic and NE Pacific) populations of Crepidula fornicata. Different styles of dashed lines represent mean diversity across all populations of the native and introduced ranges respectively. Comparisons of genetic diversity among native and introduced populations yield nonsignificant differences $(\mathrm{P}=0.99$ and $\mathrm{P}=0.85$ for microsatellites and AFLP, respectively, based on a permutation test, 5000 permutations of individuals between groups). Sources of the introduction are presumably located in the northern part of the native range. Data from Riquet et al. (2013).

Fig. 3. Increased genetic variance and admixture between genetically divergent lineages of Cyclope neritea in the NE Atlantic introduced range (red line in left map; population samples a-e) as compared to its native range in the Mediterranean and Black seas (yellow line; samples 1-13). Ephemeral populations are also documented along the Iberian Peninsula (blue line, samples f-h). Circles show the frequency distribution of mitochondrial haplotypes at 
population level. Colours indicate different groups of divergent haplotypes. Details are provided in Simon-Bouhet et al. (2006), bar for two populations (Adriatic and Black seas) that are included here but were not analysed in the paper.

Fig. 4. Potential selective processes acting during the introduction of multiple genetically polymorphic and / or divergent sources. Each colour represents individuals with a specific genetic background from the native range that may be neutral, adaptive or deleterious in the introduced range. Squares in the native range feature genetically divergent groups of individuals along the species range. Arrows in the introduced range represent temporal changes. Note that the first scenario includes temporally sequential introductions but that the same outcome may occur when the three genotypes are introduced at the same time. 
A)

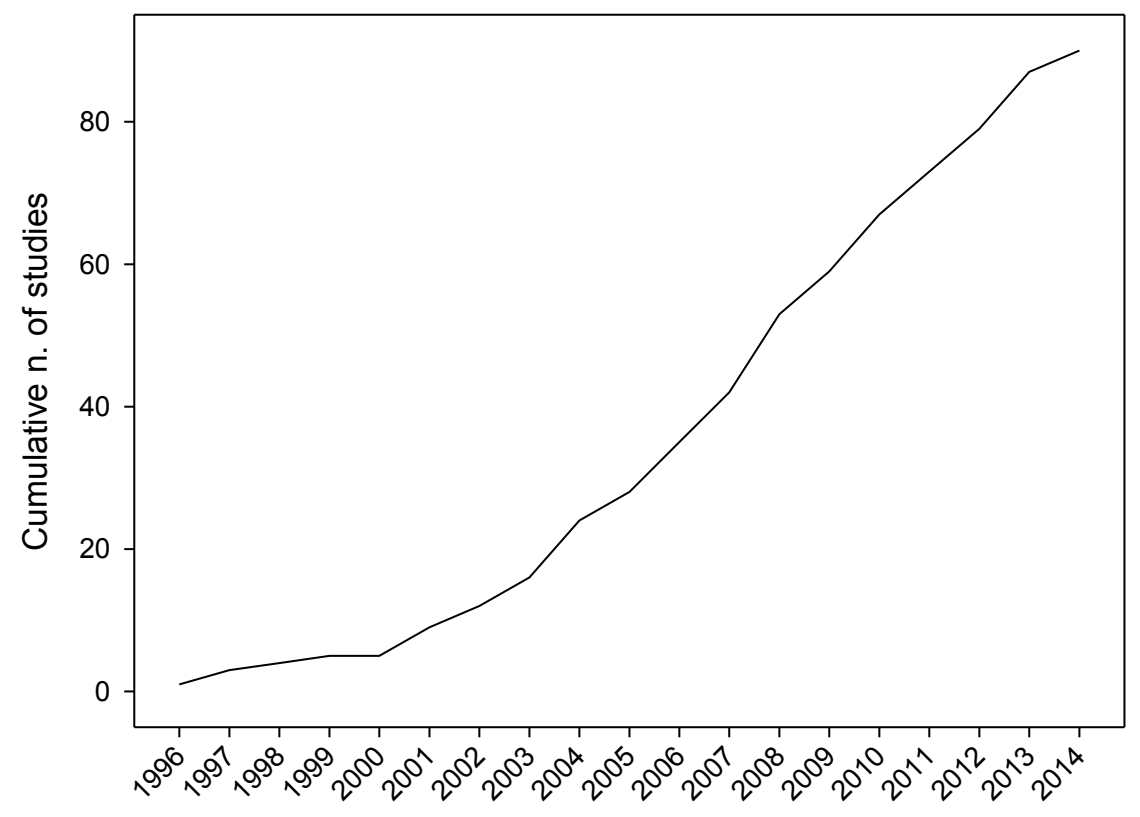

C)

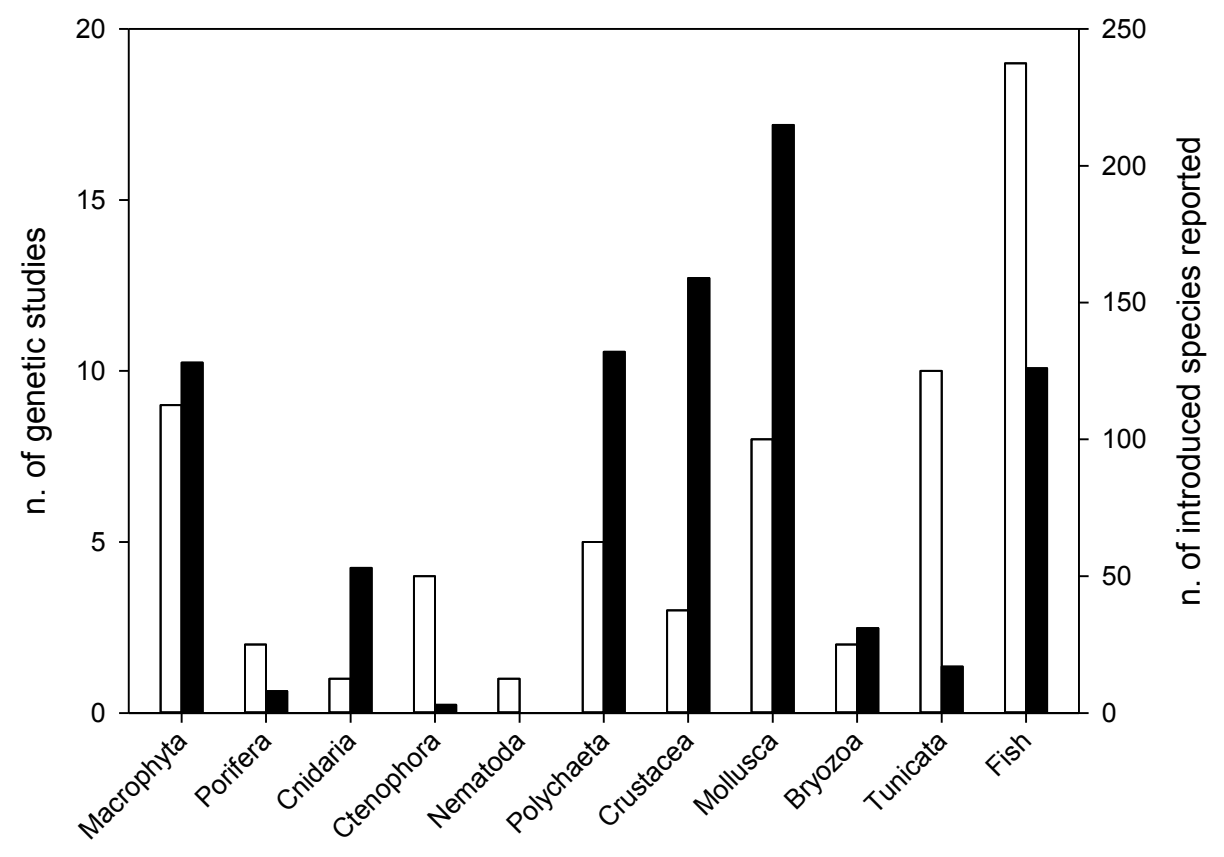

B)

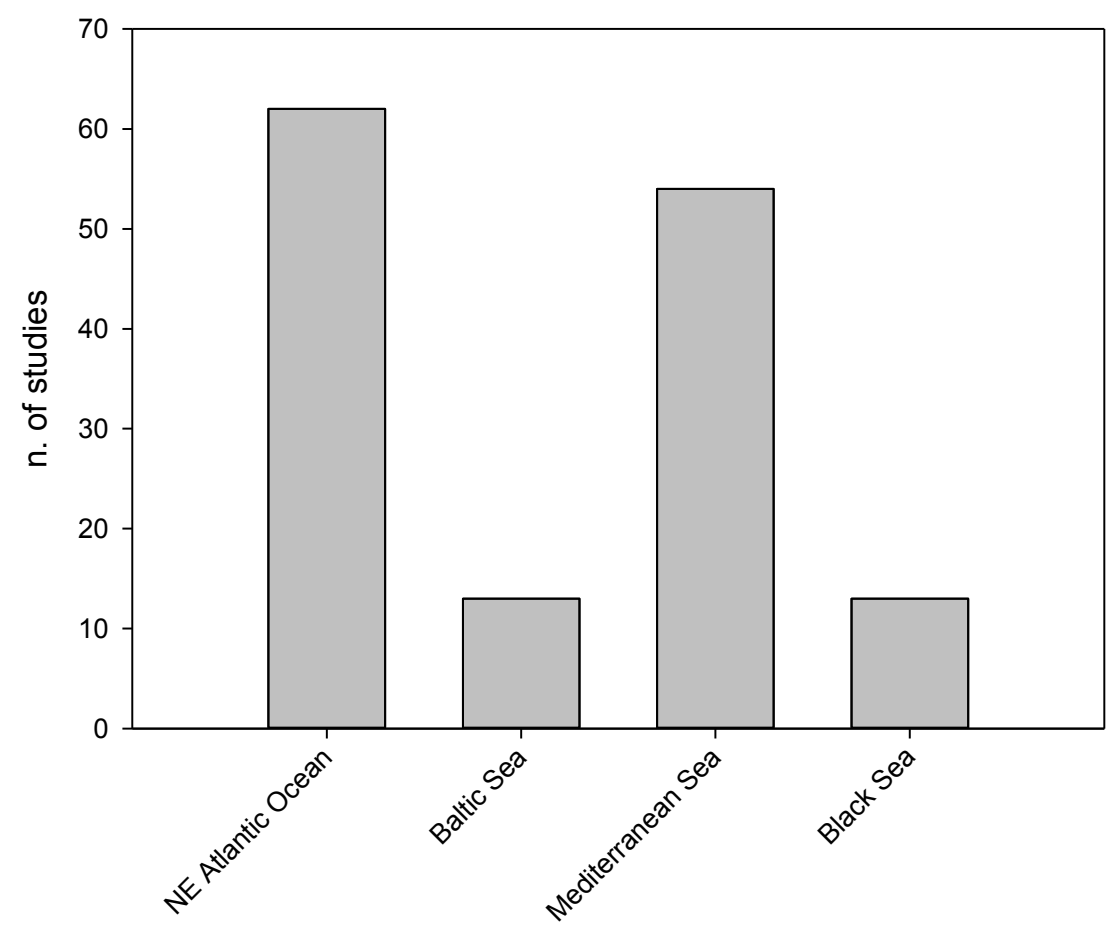

D)

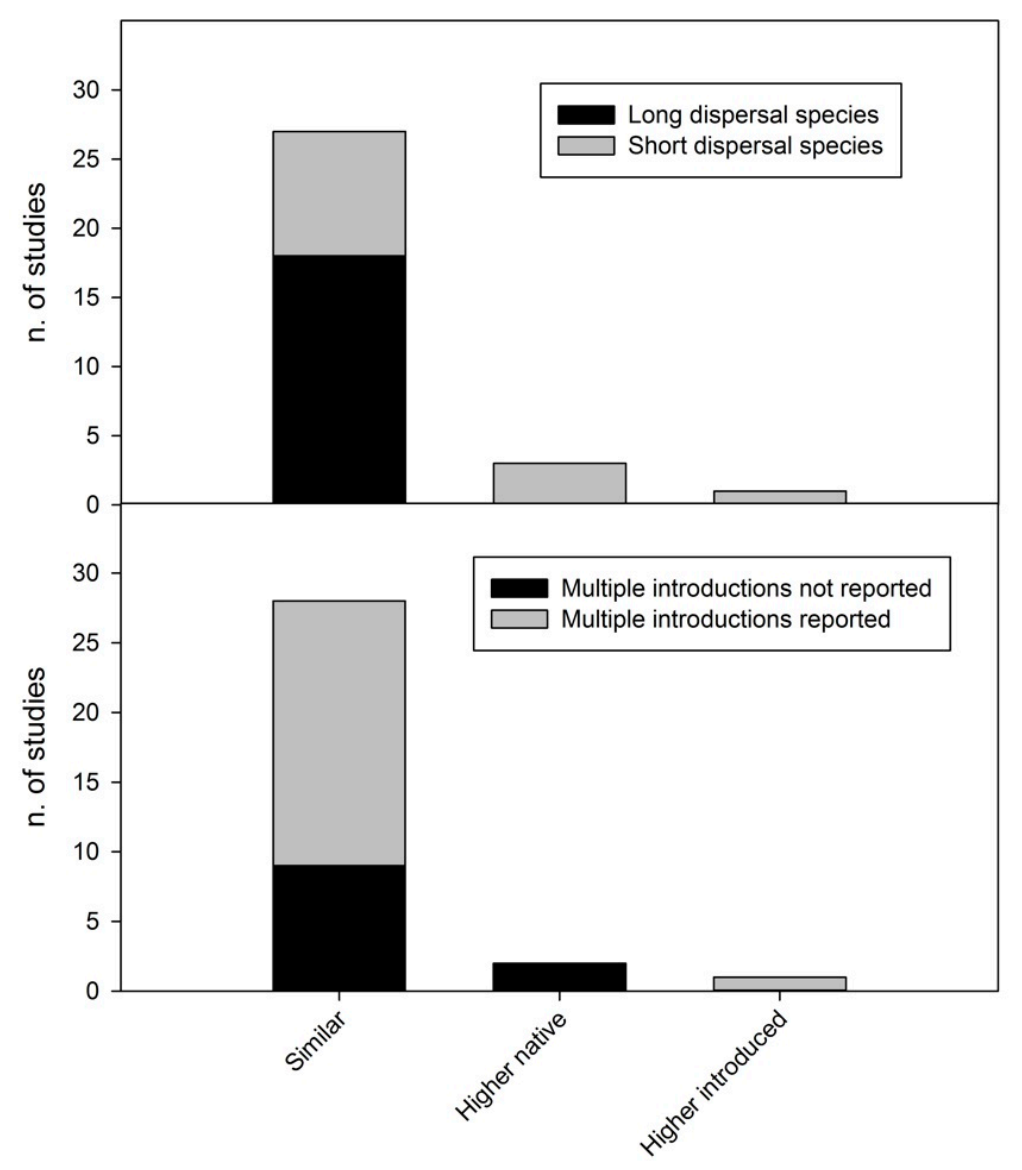

Genetic diversity of native vs introduced populations 


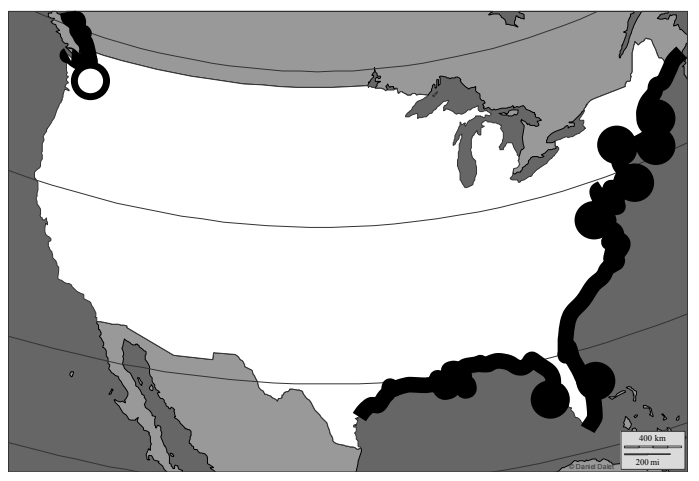

A. 17 microsatellites

- Mean native

.... Mean introduced
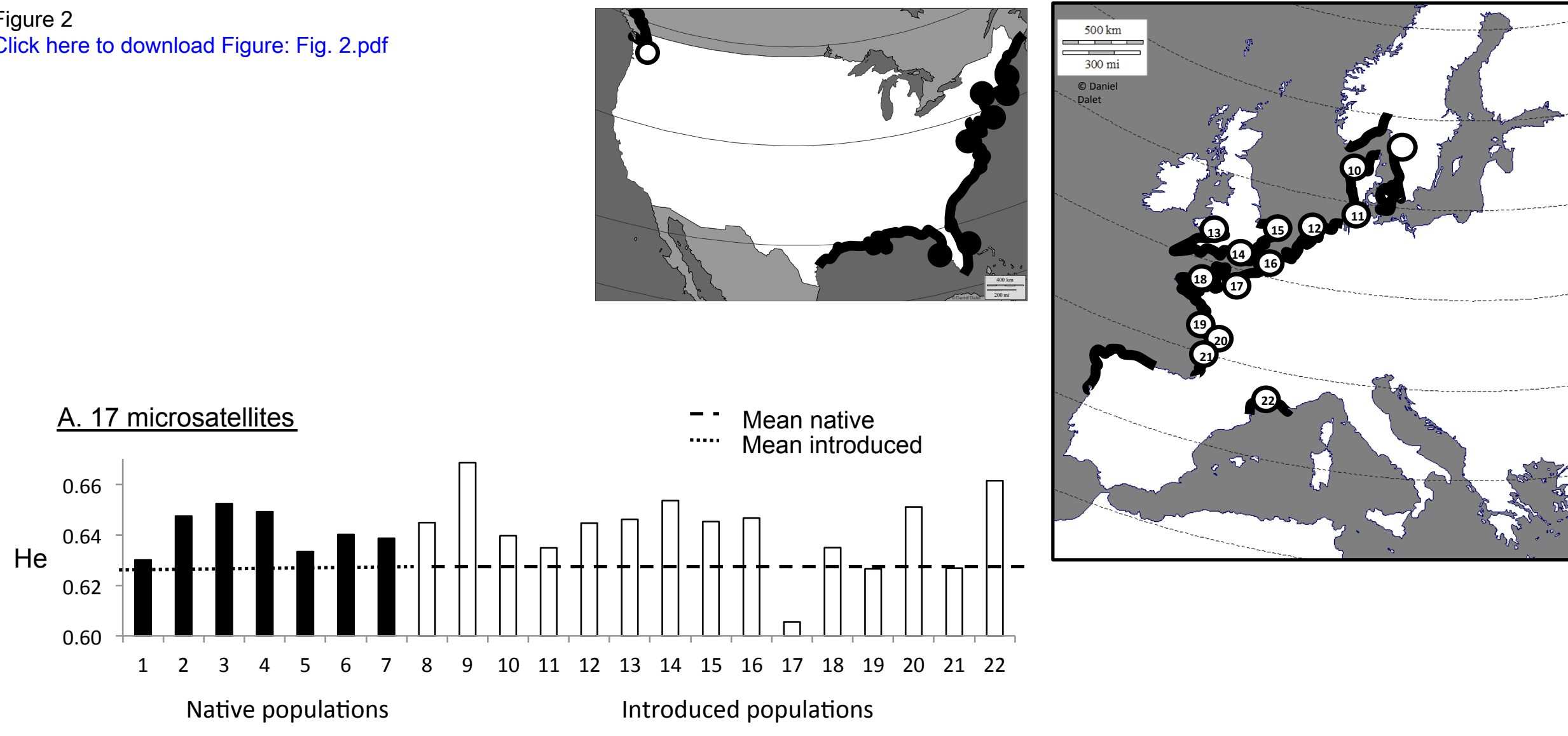

\section{B. 327 AFLPS}

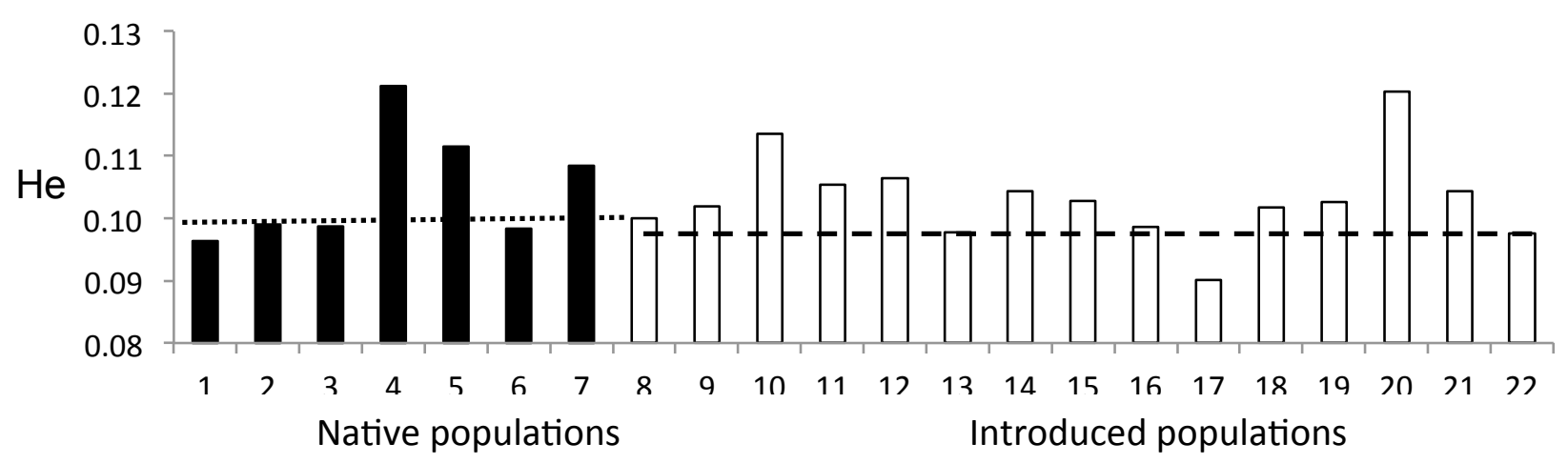



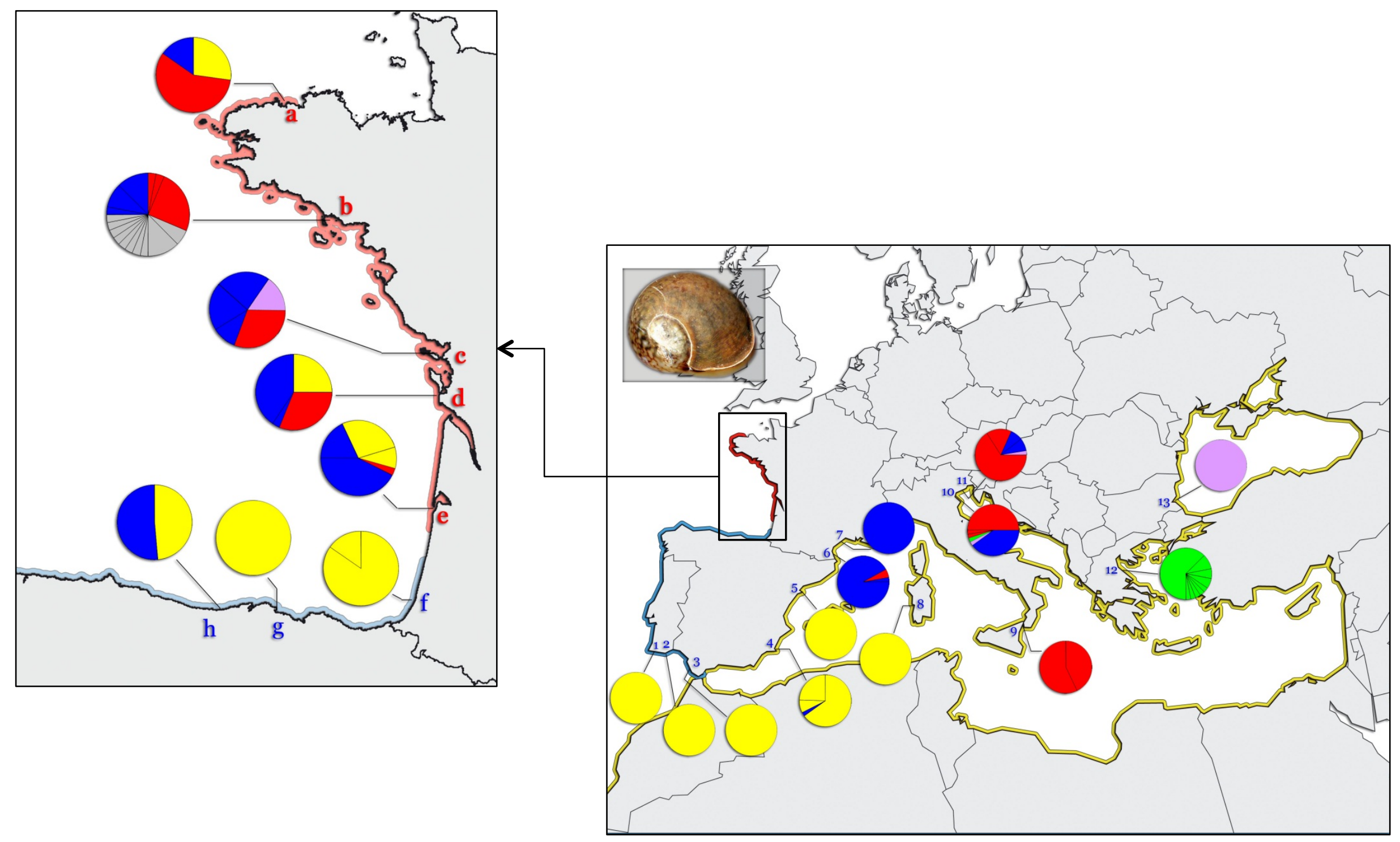
Figure 4

Click here to download Figure: Scenario 1

Repeated

introductions but

only one

introduction

(likely a pre-

adapted

genotype)

becomes

successful

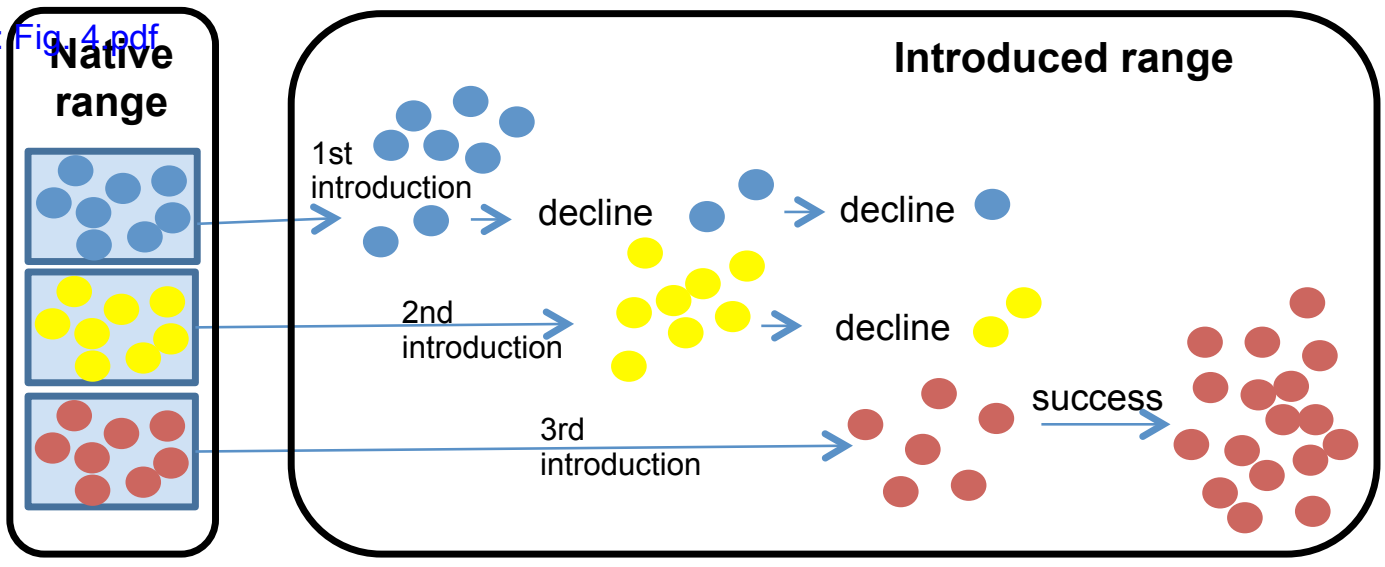

\section{Scenario 2}

Selective

forces act on

the overall

introduced

genetic

variation

\section{Scenario 3}

Evolutionary novelties arise

following genetic admixture
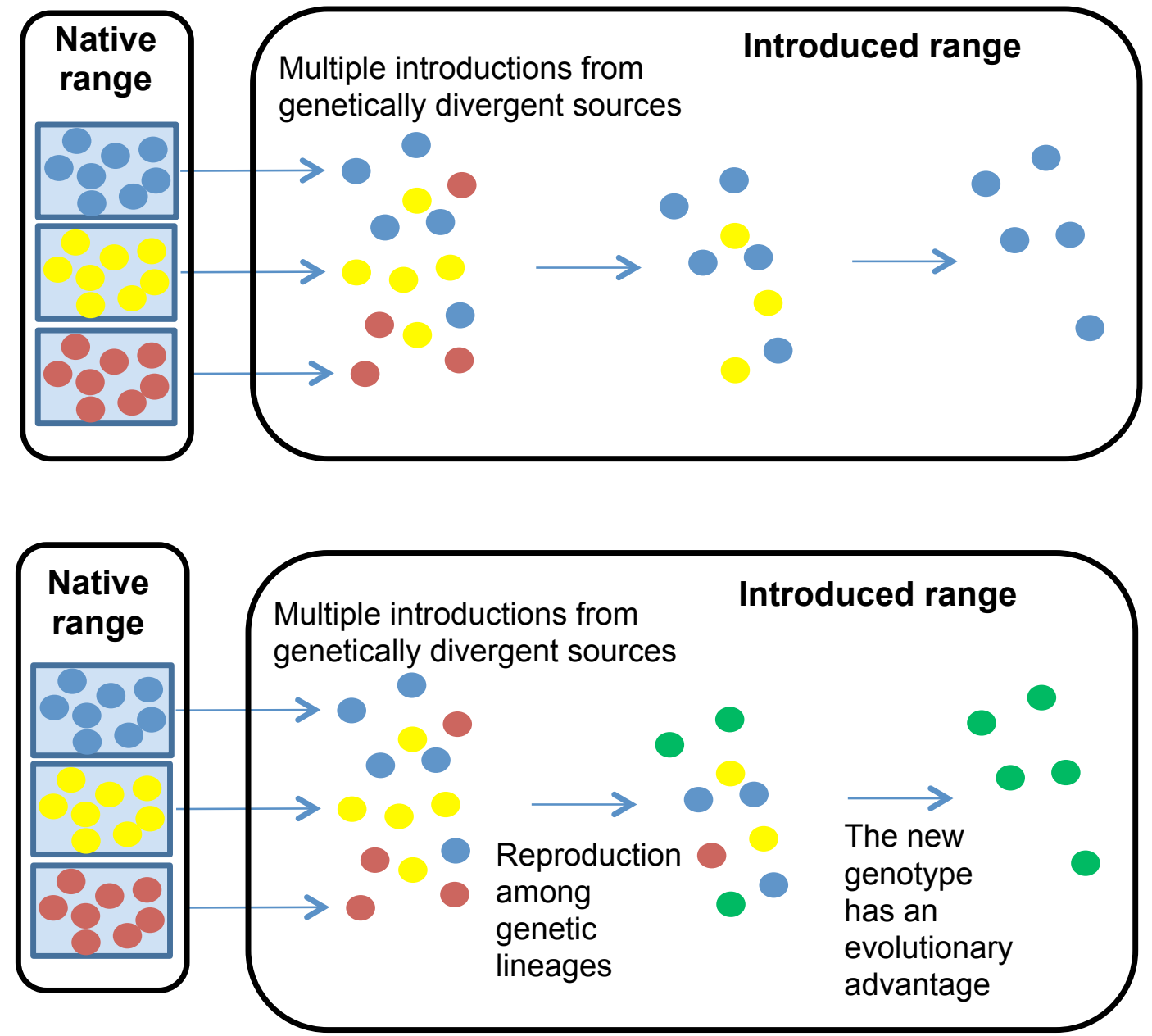